\title{
Clostridium oroticum
}

National Cancer Institute

\section{Source}

National Cancer Institute. Clostridium oroticum. NCI Thesaurus. Code C122265.

A species of mesophilic and nonmotile bacteria in the family Clostridiaceae. C. oroticum is distinguished by its occurrence as oval Gram-positive cells in chains of 100 or more units and its ability to metabolize orotic acid. 